\title{
PROPERTIES OF AN AMYLASE FROM THERMOPHILIC BACILLUS SP.
}

\author{
Raquel Vieira de Carvalho; Thamy Lívia Ribeiro Côrrea; Júlia Caroline Matos da Silva; \\ Luciana Ribeiro Coutinho de Oliveira Mansur; Meire Lelis Leal Martins*
}

\begin{abstract}
Centro de Ciências e Tecnologias Agropecuárias, Universidade Estadual do Norte Fluminense, Campos dos Goytacazes, RJ, Brasil.
\end{abstract}

Submitted: January 19, 2007; Returned to authors for corrections: July 16, 2007; Approved: January 19, 2008.

\begin{abstract}
$\alpha$-Amylase production by thermophilic Bacillus sp strain SMIA-2 cultivated in liquid cultures containing soluble starch as a carbon source and supplemented with $0.05 \%$ whey protein and $0.2 \%$ peptone reached a maximum activity at $32 \mathrm{~h}$, with levels of $37 \mathrm{U} / \mathrm{mL}$. Studies on the amylase characterization revealed that the optimum temperature of this enzyme was $90^{\circ} \mathrm{C}$. The enzyme was stable for $1 \mathrm{~h}$ at temperatures ranging from 40$50^{\circ} \mathrm{C}$ while at $90^{\circ} \mathrm{C}, 66 \%$ of its maximum activity was lost. However, in the presence of $5 \mathrm{mM} \mathrm{CaCl}_{2}$, the enzyme was stable at $90^{\circ} \mathrm{C}$ for $30 \mathrm{~min}$ and retained about $58 \%$ residual activity after $1 \mathrm{~h}$. The optimum pH of the enzyme was found to be 8.5. After incubation of enzyme for $2 \mathrm{~h}$ at $\mathrm{pH} 9.5$ and 11.0 was observed a decrease of about $6.3 \%$ and $16.5 \%$ of its original activity. At $\mathrm{pH} 6.0$ the enzyme lost about $36 \%$ of its original activity. The enzyme was strongly inhibited by $\mathrm{Co}^{2+}, \mathrm{Cu}^{2+}$ and $\mathrm{Ba}^{2+}$, but less affected by $\mathrm{Mg}^{2+}, \mathrm{Na}^{+}$and $\mathrm{K}^{+}$. In the presence of 2.0 $\mathrm{M} \mathrm{NaCl}, 63 \%$ of amylase activity was retained after $2 \mathrm{~h}$ incubation at $45^{\circ} \mathrm{C}$. The amylase exhibited more than $70 \%$ activity when incubated for $1 \mathrm{~h}$ at $50^{\circ} \mathrm{C}$ with sodium dodecyl sulphate. However, very little residual activity was obtained with sodium hypochlorite and with hydrogen peroxide the enzyme was completely inhibited. The compatibility of Bacillus sp SMIA-2 amylase with certain commercial detergents was shown to be good as the enzyme retained $86 \%, 85 \%$ and $75 \%$ of its activity after 20 min incubation at $50^{\circ} \mathrm{C}$ in the presence of the detergent brands Omo ${ }^{\circledR}$, Campeiro $^{\circledR}$ and Tide $^{\circledR}$, respectively.
\end{abstract}

Key-words: $\alpha$-Amylase, Thermophilic bacterium, Bacillus sp

\section{INTRODUCTION}

The majority of industrial enzymes used currently belong to the hydrolase group, which are active on many natural substrates. For years microorganisms have been the principal source of many different enzymes, which were identified after extensive research and currently find their main uses in industrial applications (5).

$\alpha$-Amylase (EC 3.2.1.1) is an important enzyme used in the industry and accounts for approximately $25 \%$ of the enzyme market (24). Thermostable $\alpha$-amylases have extensive commercial applications in starch processing, brewing and sugar production, desizing in textile industries and in detergent manufacturing processes $(10,15)$.
Amylases can be obtained from several sources $(1,26)$. They are usually produced by bacteria belonging to the genus Bacillus for industrial applications such as B. amyloliquefaciens, $B$. stearothermophilus, B. subtilis and Bacillus licheniformis (22), the latter now being of greater industrial importance (7). The properties of each $\alpha$-amylase such as thermostability, $\mathrm{pH}$ profile, $\mathrm{pH}$ stability, and Ca-independency must be matched to its application. For example, $\alpha$-amylases used in starch industry must be active and stable at low $\mathrm{pH}$ but in detergent industry at high $\mathrm{pH}$ values (19).

In this article, the properties of an thermostable $\alpha$-amylase produced by the thermophilic Bacillus sp strain SMIA-2, isolated from soil in Campos dos Goytacazes City, Rio de Janeiro, Brazil, are reported.

*Corresponding Author. Mailing address: Centro de Ciências e Tecnologias Agropecuárias, Universidade Estadual do Norte Fluminense. Av. Alberto Lamego, 2000. CEP. 28015-620. Campos dos Goytacazes, RJ. Brasil. Tel.: (24) 7263880; Fax: (24) 7263875. E-mail: meire@uenf.br 


\section{MATERIALS AND METHODS}

\section{Microorganism and culture conditions}

The bacterial strain used in this study was Bacillus sp SMIA-2, a thermophilic strain isolated from a local soil sample (20). Production of $\alpha$-amylase was carried out in a medium containing (g/L of distilled water): $\mathrm{KCl}-0.3, \mathrm{MgSO}_{4}-0.5, \mathrm{~K}_{2} \mathrm{HPO}_{4-}$ $0.87, \mathrm{CaCl}_{2}-2.2 \times 10^{-3}, \mathrm{ZnO}-2.5 \times 10^{-3}, \mathrm{FeCl}_{3} .6 \mathrm{H}_{2} \mathrm{O}-2.7 \times 10^{-2}$, $\mathrm{MnCl}_{2} \cdot 4 \mathrm{H}_{2} \mathrm{O}-1.0 \times 10^{-2}, \mathrm{CuCl}_{2} .2 \mathrm{H}_{2} \mathrm{O}-8.5 \times 10^{-4}, \mathrm{CoCl}_{2} \cdot 6 \mathrm{H}_{2} \mathrm{O}-2.4 \times 10^{-3}$, $\mathrm{NiCl}_{3} .6 \mathrm{H}_{2} \mathrm{O}-2.5 \times 10^{-4}, \mathrm{H}_{3} \mathrm{BO}_{3}-3.0 \times 10^{-4}$, whey protein- 0.5 , peptone2.0 and soluble starch-5.0. The $\mathrm{pH}$ was adjusted to 7.5 with $\mathrm{NaOH}$ and this basal medium was sterilized by autoclaving at $121^{\circ} \mathrm{C}$ for 15 minutes. The medium $(25 \mathrm{~mL}$ in $250 \mathrm{~mL}$ Erlenmeyer flasks) was inoculated with $1 \mathrm{~mL}$ of an overnight culture and incubated at $50^{\circ} \mathrm{C}$ in a orbital shaker (Thermo Forma, Ohio, USA) operated at $180 \mathrm{~min}^{-1}$ for $48 \mathrm{~h}$. Triplicate aliquots withdraw at regular intervals and analysed for growth (OD $600 \mathrm{~nm})$ and $\mathrm{pH}$. The cells and residues were removed from the culture broth by centrifugation and concentrated by precipitating the enzyme with ammonium sulfate (60\% saturation). The precipitate was dissolved and dialyzed overnight against $10 \mathrm{mM}$ phosphate buffer, $\mathrm{pH}$ 7.0. The dialyzed enzyme was then concentrated by lyophilization and used for subsequent studies.

\section{Amylase assay}

The activity of $\alpha$-amylase was assayed by incubating 0.5 $\mathrm{mL}$ of the diluted enzyme $\left(0.55 \mathrm{mg} . \mathrm{mL}^{-1}\right)$ with $0.5 \mathrm{~mL}$ soluble starch $(0.5 \%, \mathrm{w} / \mathrm{v})$ prepared in $0.05 \mathrm{M}$ Tris- $\mathrm{HCl}$ buffer, $\mathrm{pH} 8.5$. After incubation at $90^{\circ} \mathrm{C}$ for 10 minutes the reaction was stopped and the reducing sugars released were assayed colorimetrically by the addition of $1 \mathrm{~mL}$ of 3-5-dinitrosalicylic acid reagent (16). One enzyme activity unit (U) was defined as the amount of enzyme releasing $1 \mu \mathrm{mol}$ of glucose from the substrate in 1 minute at $90^{\circ} \mathrm{C}$.

\section{Effect of the $\mathrm{pH}$}

The effect of $\mathrm{pH}$ on the activity of $\alpha$-amylase was measured by incubating $0.5 \mathrm{~mL}$ of the diluted enzyme $\left(0.55 \mathrm{mg} \cdot \mathrm{mL}^{-1}\right)$ and $0.5 \mathrm{~mL}$ of buffers presenting $\mathrm{pH}$ from 6.0 to 12.0 , containing $0.5 \%$ soluble starch for 10 minutes at $90^{\circ} \mathrm{C}$. The buffers used were: phosphate buffer, $\mathrm{pH}$ 6.0-8.0; Tris- $\mathrm{HCl}$ buffer, $\mathrm{pH}$ 8.5-9.0 and glycine- $\mathrm{NaOH}, \mathrm{pH} 10.0-12.0$. The stability of the enzyme at different $\mathrm{pH}$ values was also studied by incubating the enzyme at various $\mathrm{pH}$ values ranging from 6.0 to12.0 for $2 \mathrm{~h}$ and then estimating the residual activity.

\section{Effect of temperature}

The effect of temperature on the enzyme activity was determined by performing the previously described standard assay procedure for 10 minutes at $\mathrm{pH} 8.5$ within a temperature range of $40-100^{\circ} \mathrm{C}$. Thermostability was determined by incubation of the lyophilized enzyme at temperatures ranging from $40-100^{\circ} \mathrm{C}$ for $1 \mathrm{~h}$ in a constant-temperature water bath. After treatment the residual enzyme activity was assayed.

\section{Effect of metal ions}

The effect of metal ions on $\alpha$-amylase activity was measured incubating the enzyme at $90^{\circ} \mathrm{C}$ for $2 \mathrm{~min}$ with various metal ions at a concentration of $5 \mathrm{mM}$ and $10 \mathrm{mM}$. The enzyme assay was carried out in the presence of $\mathrm{Ca}^{2+}, \mathrm{Zn}^{2+}, \mathrm{Mn}^{2+}, \mathrm{Ni}^{2+}$ and $\mathrm{Ba}^{2+}$ chlorides, and $\mathrm{Mg}^{2+}, \mathrm{Fe}^{2+}, \mathrm{Co}^{2+}$ and $\mathrm{Cu}^{2+}$ sulphates.

\section{Salt tolerance test}

The enzyme was incubated in $50 \mathrm{mM}$ Tris- $\mathrm{HCl}$ buffer $(\mathrm{pH}$ 8.5) containing $\mathrm{NaCl}$ at concentrations of 0 to $5 \mathrm{M}$ for 120 minutes at $45^{\circ} \mathrm{C}$. The activity of the enzyme was measured in the same way as mentioned earlier.

\section{Effect of inhibitors and oxidizing agents}

The enzyme was incubated with $5 \mathrm{mM}$ sodium dodecylsulphate (SDS), sodium hypochlorite $(\mathrm{NaClO})$, hydrogen peroxide $\left(\mathrm{H}_{2} \mathrm{O}_{2}\right)$ and EDTA (Ethylene diaminetetraacetic acid) at $50^{\circ} \mathrm{C}$ for $1 \mathrm{~h}$. After incubation, the residual activity was determined by the standard enzyme assay. The results were recorded as the percentage of residual activity calculated with reference to activity controls incubated in the absence of these compounds.

\section{Evaluation of enzyme for use in detergent formulation}

The detergent brands used were Ariel $^{\circledR}$, Biz $^{\circledR}$, Cheer $^{\circledR}$, Tide $^{\circledR}$, $\mathrm{Campeiro}^{\circledast}$ and $\mathrm{Omo}^{\circledR}$. They were diluted in double distilled water to a final concentration of $7 \mathrm{mg} \cdot \mathrm{mL}^{-1}$ to simulate washing conditions and heated at $100^{\circ} \mathrm{C}$ for 15 minutes to inactivate the enzymes that could be part of their formulation. The detergents were added to the reaction mixture and the reaction was carried out under standard assay conditions. To determine the stability of Bacillus sp SMIA-2 amylase in the presence of the different detergents, an amylase concentration of $1 \mathrm{mg} \cdot \mathrm{mL}^{-1}$ was added in detergent solution and incubated at $50^{\circ} \mathrm{C}$ for 60 minutes. Aliquots $(0.5 \mathrm{~mL})$ were taken at different time intervals and the residual activity determined at $90^{\circ} \mathrm{C}$ and compared with the control sample incubated at $50^{\circ} \mathrm{C}$ without any detergent $(2,21)$.

\section{RESULTS AND DISCUSSION}

\section{Enzymatic production}

Fig. 1 shows the time-course profile of amylase production by Bacillus sp strain SMIA-2 in basal medium containing soluble starch $(0.5 \%)$ as a carbon source and supplemented with whey protein $(0.05 \%)$ and peptone $(0.2 \%)$. $\alpha$-amylase production by Bacillus sp strain SMIA-2 began in the exponential growth phase, reaching a maximum at $32 \mathrm{~h}$, with levels of $37 \mathrm{U} / \mathrm{mL}$. Subsequently amylase levels remained more or less the same up to $36 \mathrm{~h}$ and then dropped to $30 \mathrm{U} / \mathrm{mL}$ at $48 \mathrm{~h}$. The $\mathrm{pH}$ of the 


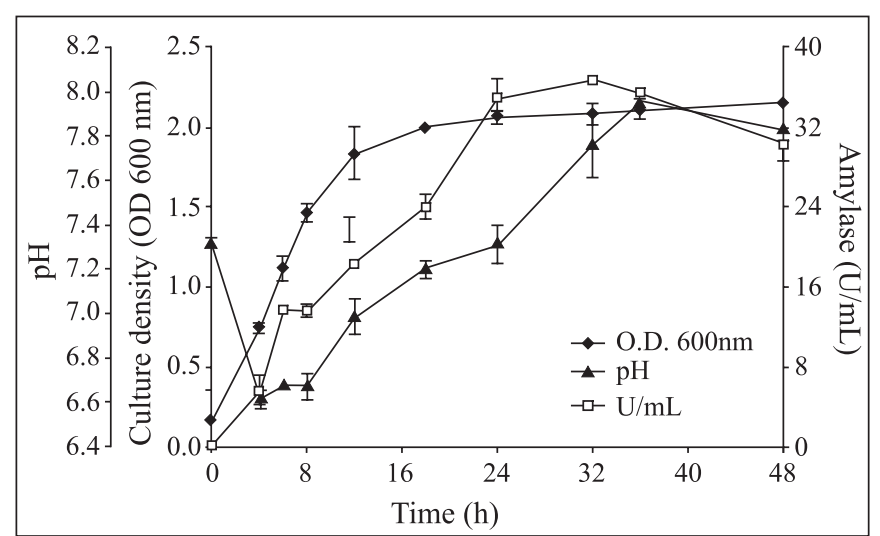

Figure 1. Time course of $\alpha$-amylase production by Bacillus sp strain SMIA-2 grown at $50^{\circ} \mathrm{C}$ on soluble starch $(0.5 \%)$ in shake flasks. Results represent the means of three separate experiments, and bars indicated \pm 1 standard deviation. Absence of bars indicates that errors were smaller than symbols.

medium dropped as cells started to grow, but as soon as enzyme production was initiated, the $\mathrm{pH}$ started to rise. This may indicate that some organic nitrogen was being consumed. The end of enzyme production was signalled by a slight decrease of $\mathrm{pH}$. Thus the $\mathrm{pH}$ profile provides a useful means of monitoring the production process.

\section{Effect of the pH}

The effect of $\mathrm{pH}$ on $\alpha$-amylase activity as a function of $\mathrm{pH}$ is shown in Fig. 2. Optimum pH was found to be 8.5. The enzyme activity at $\mathrm{pH} 7.0$ and 11.0 were $72 \%$ and $81.4 \%$ of that at $\mathrm{pH} 8.5$, respectively. After incubation of the enzyme solution for $2 \mathrm{~h}$ at $\mathrm{pH} 6.0-12.0$, the original activity at $\mathrm{pH} 9.5$ decreased by $63 \%$ and at $\mathrm{pH} 11.0$ the decrease was $16.5 \%$. However, at $\mathrm{pH} 6.0$, the original activity decreased $36 \%$. These results suggest that the activity of the enzyme is higher in alkaline $\mathrm{pH}$, making this enzyme attractive for the detergent industry. $\alpha$-amylases produced by other Bacillus sp have shown optimum activities at $\mathrm{pH}$ values as low as 3.5 or as high as $12(3,13)$.

\section{Effect of temperature}

Fig. 3 shows the activity of the lyophilized enzyme preparation assayed at temperatures ranging from $40^{\circ} \mathrm{C}-100^{\circ} \mathrm{C}$ at $\mathrm{pH} 8.5$ and a substrate concentration of $0.5 \%$. Enzyme activity increased with temperature within the range of $40^{\circ} \mathrm{C}$ to $90^{\circ} \mathrm{C}$. A reduction in enzyme activity was observed at values above $90^{\circ} \mathrm{C}$. The optimum temperature of this $\alpha$-amylase was $90^{\circ} \mathrm{C}$, which was higher or similar to that described for other Bacillus $\alpha$-amylases $(4,6,12,13,24)$.

The residual activities of crude amylase incubated at different temperatures for a period of $1 \mathrm{~h}$ were estimated at optimum temperature. The enzyme was stable for $1 \mathrm{~h}$ at temperatures

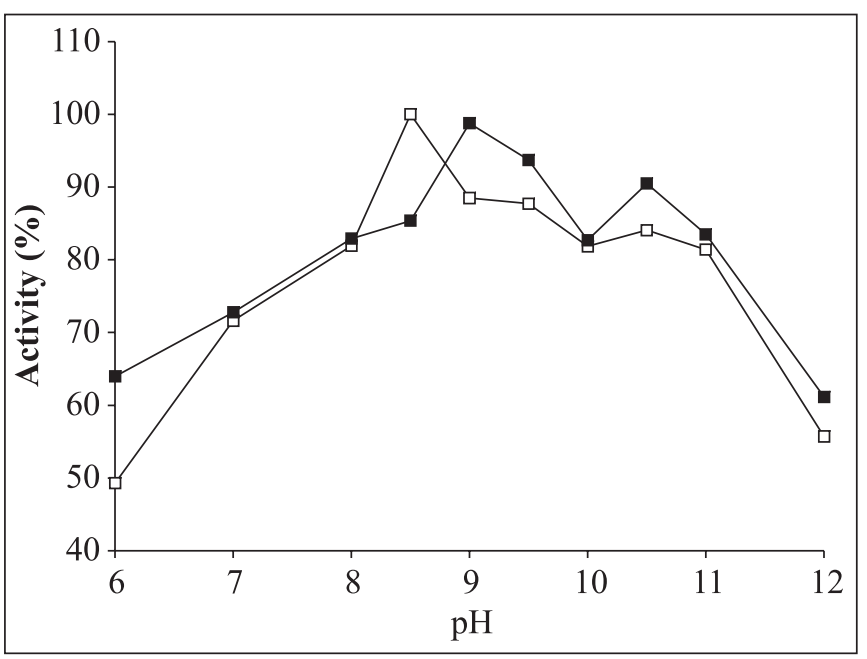

Figure 2. Optimum pH ( $\square$ ) and stability ( $\square$ ) of $\alpha$-amylase produced by Bacillus sp strain SMIA-2 grown at $50^{\circ} \mathrm{C}$ for $48 \mathrm{~h}$. Relative activity is expressed as a percentage of the maximum $(100 \%$ of enzyme activity $=36.1 \mathrm{U} / \mathrm{mL})$.

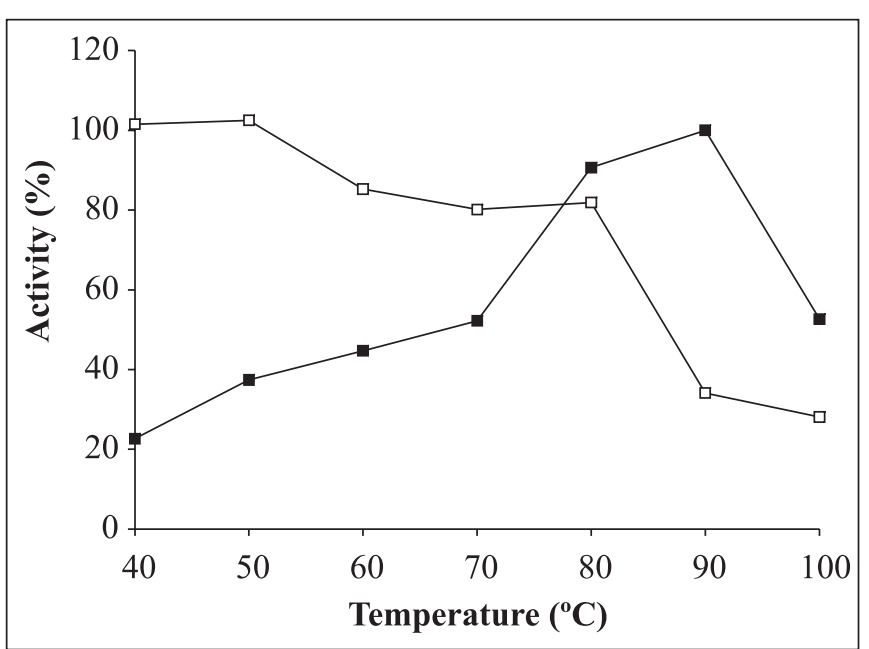

Figure 3. Optimum temperature ( $\mathbf{\square}$ ) and stability temperature ( $\square$ ) of $\alpha$-amylase produced by Bacillus sp strain SMIA- 2 grown at $50^{\circ} \mathrm{C}$ for $48 \mathrm{~h}$. Relative activity is expressed as a percentage of the maximum. $100 \%$ of enzyme activity $=36.4 \mathrm{U} / \mathrm{mL}$.

ranging from $40-50^{\circ} \mathrm{C}$ while at $80^{\circ} \mathrm{C}, 18 \%$ of its maximum activity was lost. At $90^{\circ} \mathrm{C}, 66 \%$ of its maximum activity was lost, however, the addition of $5 \mathrm{mM} \mathrm{CaCl}_{2}$ improved the thermostability of the amylase, as indicated in Fig. 4. The enzyme was stable at $90^{\circ} \mathrm{C}$ for $30 \mathrm{~min}$ and retained about $50.6 \%$ residual activity after $1 \mathrm{~h}$. The requirement of $\mathrm{Ca}^{2+}$ by $\alpha$-amylases for their stability at higher temperature has also been reported for Bacillus sp. I-3 (9), Bacillus sp. ANT-6 (6), B. subtilis (18), Bacillus clausii BT- 


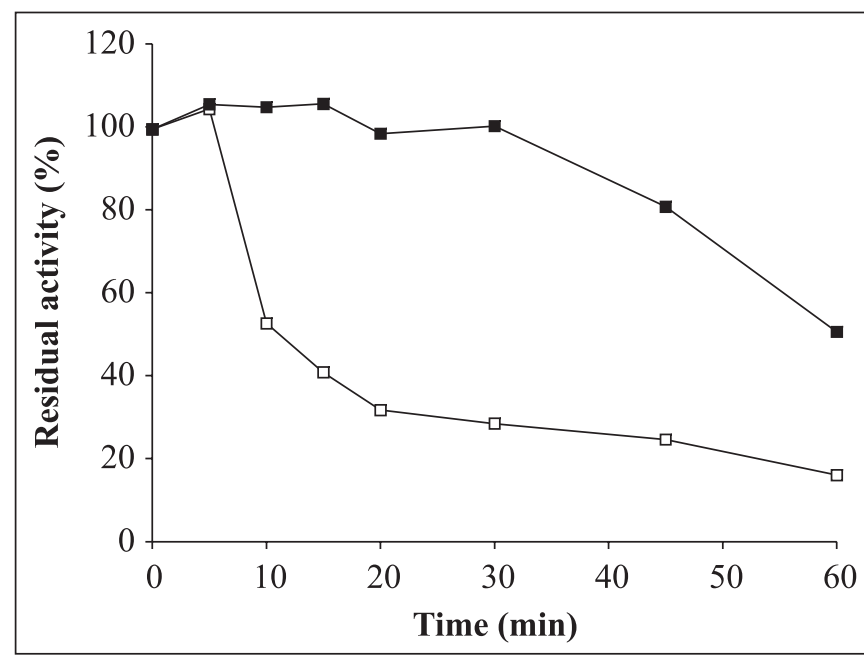

Figure 4. Termostability of amylase at $90^{\circ} \mathrm{C}$ in the presence or absence of $\mathrm{Ca}^{2+}(\square) .100 \%$ of enzyme activity $=50.5 \mathrm{U} / \mathrm{mL}$.

21 (8), and Bacillus licheniformis (14). The stabilizing effect of $\mathrm{Ca}^{2+}$ on thermostability of the enzyme can be explained by the salting out of the hydrophobic residues by $\mathrm{Ca}^{2+}$ in the protein, thus causing the adoption of a compact structure (27).

\section{Effect of metal ions}

The amylase did not require any specific ion for catalytic activity (Fig. 5). Najafi et al. (2005) observed that the $\alpha$-amylase from Bacillus subtilis AX20 did not have an obligate requirement for divalent metal ions to be active and its activity was not stimulated in the presence of metal ions. A stronger inhibitory effect was observed in the presence of $\mathrm{Cu}^{2+}, \mathrm{Co}^{2+}, \mathrm{Ba}^{2+}$ and $\mathrm{Mn}^{2+}$. On the other hand, no significant inhibition of activity was observed in the presence of $5 \mathrm{mM}$ of $\mathrm{Mg}^{2+}, \mathrm{Na}^{+}, \mathrm{Zn}^{2+}$ and $\mathrm{K}^{+}$. Some amylases are metalloenzymes, containing a metal ion with a role in catalytic activity. The inhibition of Bacillus sp strain SMIA2 amylase by $\mathrm{Co}^{2+}, \mathrm{Cu}^{2+}$ and $\mathrm{Ba}^{2+}$ ions could be due to competition between the exogenous cations and the protein-associated cation, resulting in decreased metalloenzyme activity (15).

\section{Salt tolerance test}

In the presence of $2.0 \mathrm{M} \mathrm{NaCl}, 63.4 \%$ of amylase activity was retained after $2 \mathrm{~h}$ incubation at $45^{\circ} \mathrm{C}$ (Fig. 6). The $\alpha$-amylase produced by Bacillus sp. MD 124 was stable in $\mathrm{NaCl}$ solution and retained $75 \%$ of its original activity in $5 \mathrm{M}$ after $24 \mathrm{~h}$ of incubation (11).

Effect of inhibitors and some oxidizing agents on enzyme activity and compatibility with various commercial detergents

Besides $\mathrm{pH}$ and temperature stability, a good detergent amylase should also be stable to various detergent ingredients, such as surfactants, chelators and oxidants (23). The amylase

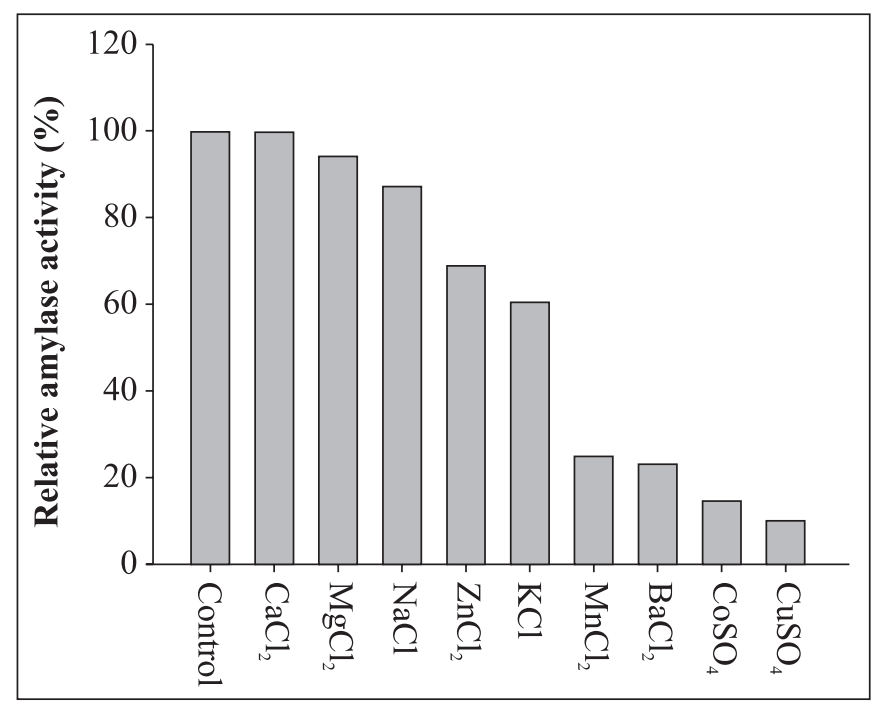

Figure 5. Effect of metal ions on amylase activity. The activity is expressed as a percentage of the activity level in the absence of metal ion. $100 \%$ of enzyme activity $=40.62 \mathrm{U} / \mathrm{mL}$.

from Bacillus sp SMIA-2 retained more than $70 \%$ activity after incubated for $1 \mathrm{~h}$ at $50^{\circ} \mathrm{C}$ with sodium dodecyl sulphate, an anionic detergent (Fig. 7). However, very little residual activity was obtained with sodium hypochlorite. The enzyme was completely inhibited by hydrogen peroxide. The amylase from Bacillus sp. PN5 retained more than $80 \%$ activity when incubated with sodium perborate and sodium dodecyl sulphate and more than $70 \%$ activity when incubated with hydrogen

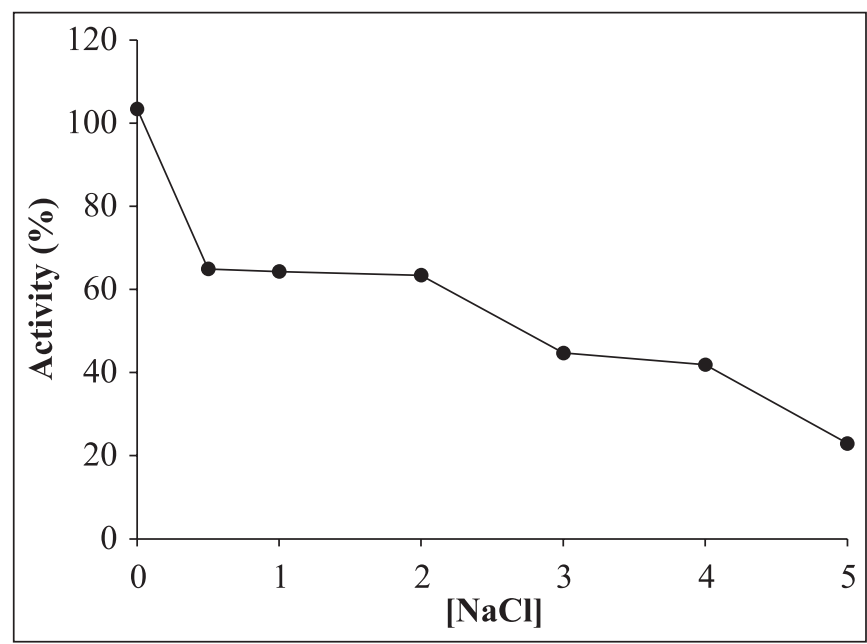

Figure 6. Effect of $\mathrm{NaCl}$ concentration on $\alpha$-amylase produced by Bacillus sp strain SMIA-2 grown at $50^{\circ} \mathrm{C}$ for $24 \mathrm{~h}$. Relative activity is expressed as a percentage of the maximum. $100 \%$ of enzyme activity $=34.8 \mathrm{U} / \mathrm{mL}$. 


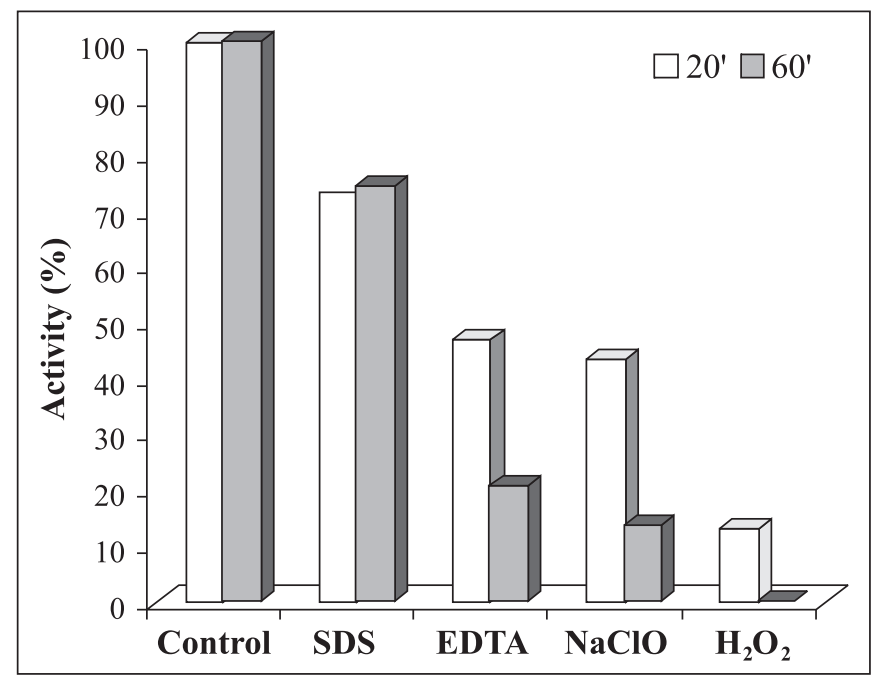

Figure 7. Effect of inhibitors and oxidizing agents on $\alpha$-amylase activity. The activity is expressed as a percentage of the activity level in the absence of inhibitors and oxidizing agents. $100 \%$ of enzyme activity $=31.9 \mathrm{U} / \mathrm{mL}$.

peroxide for an hour. However, very little residual activity was obtained with sodium hypochlorite (23). Regarding to the effect of EDTA, the enzyme retained $53 \%$ of its activity when incubated for $20 \mathrm{~min}$ at $50^{\circ} \mathrm{C}$. The $\alpha$-amylase from Bacillus sp PS-7 retained almost $100 \%$ activity when 1mM EDTA was added to the reaction mixture (25).
Studies on the effect of detergents on amylase activity (Fig. 8a) show that the enzyme activity increased in the presence of $\mathrm{Omo}^{\circledR}$ and was almost the same as that of the control in the presence of Campeiro ${ }^{\circledR}$. On the other hand, the enzyme was severely inhibited in the presence of $\mathrm{Biz}^{\circledR}$ and $\mathrm{Cheer}^{\circledR}$. The compatibility of Bacillus sp. SMIA-2 amylase with certain commercial detergents was shown to be good as the enzyme retained $86 \%, 85 \%$ and $75 \%$ of its activity after 20 minutes incubation at $50^{\circ} \mathrm{C}$ in the presence of the detergent brands $\mathrm{Omo}^{\circledR}$, Campeiro $^{\circledR}$ and Tide ${ }^{\circledR}$ respectively (Fig. 8b). After 40 minutes, the enzyme retained $49 \%, 47 \%$ and $40 \%$ activity at $50^{\circ} \mathrm{C}$ in the presence of the detergents $\mathrm{Tide}^{\circledR}, \mathrm{Omo}^{\circledR}$ and Campeiro ${ }^{\circledR}$ respectively.

\section{ACKNOWLEDGMENTS}

The authors are highly thankful to the Fundação de Amparo à Pesquisa do Estado do Rio de Janeiro for financial support.

\section{RESUMO}

\section{Propriedades de uma amilase de um termofílico Bacillus sp}

A produção de $\alpha$-amilase por um termofilico, Bacillus sp SMIA-2, cultivado em meio líquido contendo amido solúvel como fonte de carbono, alcançou uma atividade máxima de 37 U/mL em 32 horas. Estudos sobre a caracterização da amilase revelaram que a temperatura ótima desta enzima foi $90^{\circ} \mathrm{C}$. A

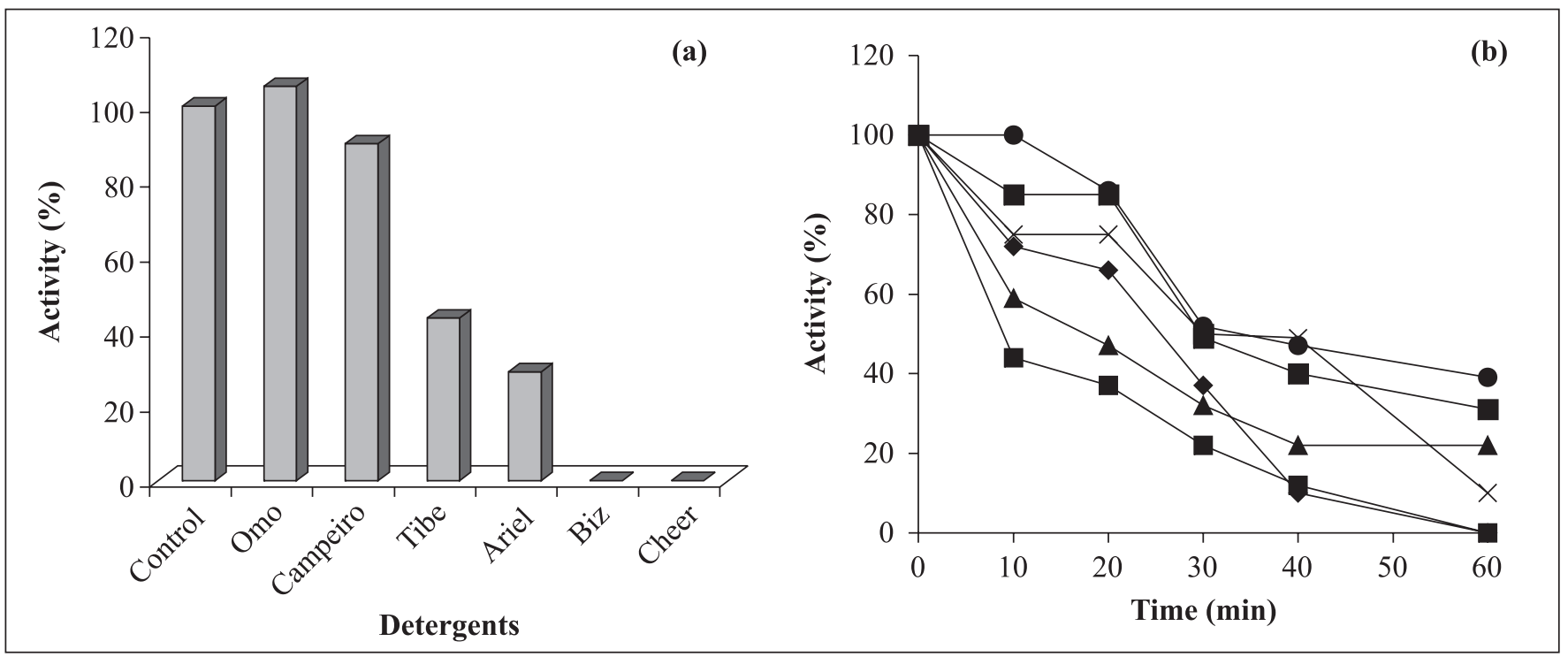

Figure 8. Compatibility of $\alpha$-amylase activity from Bacillus sp. SMIA-2 with commercial detergents $\left(\bullet\right.$ Ariel $^{\circledR}, \boldsymbol{\square}$ Biz $^{\circledR}, \Delta$ Cheer $^{\circledR}$, $\times$ Tide $^{\circledR}, \square$ Campeiro $\left.^{\circledR},-\mathrm{Omo}^{\circledR}\right)$. The activity is expressed as a percentage of the activity level in the absence of detergents $(100 \%$ of enzyme activity $=47 \mathrm{U} / \mathrm{mL})$. 
enzima foi estável por 1 hora a temperaturas de 40 e $50^{\circ} \mathrm{C}$ enquanto a $90^{\circ} \mathrm{C}, 66 \%$ da atividade máxima foi perdida. Entretanto, na presença de $5 \mathrm{mM} \mathrm{de} \mathrm{CaCl}_{-2}$, a enzima foi estável a $90^{\circ} \mathrm{C}$ por 30 minutos e manteve cerca de $58 \%$ de sua atividade residual por 1 hora. $\mathrm{O}$ pH ótimo da enzima encontrado foi de 8.5. Após a incubação da enzima por 2 horas a pH 9.5 e 11.0 foi observado um decréscimo de aproximadamente $6.3 \%$ e $16.5 \%$ da atividade original. Em pH 6.0 a enzima perdeu cerca de $36 \%$ de sua atividade original. A enzima foi fortemente inibida por $\mathrm{Co}^{2+}, \mathrm{Cu}^{2+}, \mathrm{e} \mathrm{Ba}^{2+}$, porém pouco afetada por $\mathrm{Mg}^{2+}, \mathrm{Na}^{+} \mathrm{e} \mathrm{K}$. Na presença de $2.0 \mathrm{M}$ de $\mathrm{NaCl}, 63 \%$ da atividade da amilase foi mantida após 2 horas de incubação a temperatura de $45^{\circ} \mathrm{C}$. A amilase exibiu atividade acima de $70 \%$ quando incubada por 1 hora a $50^{\circ} \mathrm{C} \mathrm{em}$ presença de sódio dodecil sufato (SDS). Entretanto, uma baixa atividade residual foi obtida quando na presença do hipoclorito de sódio e uma completa inibição quando a enzima foi incubada em peróxido de hidrogênio. A compatibilidade da amilase produzida pelo Bacillus sp SMIA-2, em relação a alguns detergentes comerciais mostrou que a enzima manteve $86 \%, 85 \%$, e $75 \%$ da atividade após 20 minutos de incubação a $50^{\circ} \mathrm{C}$ na presença dos detergentes $\mathrm{Omo}^{\circledR}$, Campeiro $^{\circledR}$ e $^{\text {Tide }}{ }^{\circledR}$, respectivamente.

Palavras-chave: $\alpha$-Amilase, Bactéria termofílica, Bacillus sp.

\section{REFERENCES}

1. Aquino, A.C.M.M.; Jorge, J.A.; Terenzi, H.F.; Polizeli, M.L.T.M. (2003). Studies on a thermostable $\alpha$-amylase from the thermophilic fungus Scytalidium thermophilum. Appl. Microbiol. Biotechnol., 61, 323-328.

2. Banerjee, U.C.; Sani, R.K.; Azmi, W.; Soni, R. (1999). Thermoestable alkaline protease from Bacillus brevis and its characterization as a laundry detergent additive. Process Biochem., 35, 213-219.

3. Bernhardsdotter, E.C.M.J.; Ng, J.D.; Garriott, O.K.; Pusey, M.L. (2005). Enzymic properties of an alkaline chelator-resistant $\alpha$ amylase from an alkaliphilic Bacillus sp. isolate L1711. Process Biochem., 40, 2401-2408.

4. Bertoldo, C.; Antranikian, G. (2002). Starch hydrolyzing enzymes from thermophilic archae and bacteria. Curr. Opin. Chem. Biol., 6, 151-160

5. Bon, E.P.S. (1995). A tecnologia enzimática no Brasil, ENZITEC, 95, 9-14.

6. Burhan, A.; Nisa, U.; Gokhan, C.; Omer, C.; Ashabil, A.; Osman, G. (2003). Enzymatic properties of a novel thermostable, thermophilic, alkaline and chelator resistant amylase from an alkaliphilic Bacillus sp. isolate ANT-6. Process Biochem., 38, 1397-403.

7. Declerck, N.; Machius, M.; Wiegand, G.; Huber, R.; Gaillardin, C. (2000). Probing structural determinants specifying high thermostability in Bacillus licheniformis $\alpha$-amylase. J. Mol. Biol., 31, 1041-1057.

8. Duedahl-Olesen, L.; Kragh, K.M.; Zimmermann, W. (2000). Purification and characterisation of a malto-oligosaccharide-forming amylase active at high $\mathrm{pH}$ from Bacillus clausii BT-21. Carbohydr. Res., 329, 97-107.

9. Goyal, N.; Gupta, J.K.; Soni, S.K. (2005). A novel raw starch digesting thermostable $\alpha$-amylase from Bacillus sp.I-3 and its use in the direct hydrolysis of raw potato starch. Enzyme and Microb. Technol., 37, 723-734.

10. Hendriksen, H.V.; Pedersen, S.; Bisgard-Frantzen, H. (1999). A process for textile warp sizing using enzymatically modified starches. Patent Application, WO 99/35325.

11. Jana, M.; Pati, B. (1997). Thermostable, salt-tolerant $\alpha$-amylase from Bacillus sp. MD-124. J. Bras. Microbiol., 37, 323-326.

12. Jin, F.; Li, Y.; Zhang, C.; Yu, H. (2001). Thermostable $\alpha$-amylase and a-galactosidase production from the thermophilic and aerobic Bacillus sp. JF strain. Process Biochem., 36, 559-564.

13. Konsula, Z.; Liakopoulou-Kyriakides, M. (2004). Hydrolysis of starches by the action of an $\alpha$-amylase from Bacillus subtilis. Process Biochem., 39, 1745-1749.

14. Krishnan T.; Chandra A.K. (1983). Purification and characterization of $\alpha$-amylase from $B$. licheniformis CUMC 305. Appl. Environ. Microbiol., 46, 430-437.

15. Lévêque, E.; Janecek, S.; Haye, B.; Belarbi, A. (2000). Thermophilic archaeal amylolytic enzymes. Enzyme Microbiol. Technol., 26, 3-14.

16. Miller, G.L. (1959). Use of dinitrosalicylic acid reagent for determination of reducing sugars. Anal. Chem., 3, 426-428.

17. Najafi, M.F.; Deobagkar, D.; Deobagkar, D. (2005). Purification and characterization of an extracellular $\alpha$-amylase from Bacillus subtilis AX20. Protein Expr. and Purif., 41(2), 349-354.

18. Nielsen, A.D.; Pusey, M.L.; Fuglsang, C.C.; Westh, P. (2003). A proposed mechanism for the thermal denaturation of a recombinant Bacillus halmapalus $\alpha$-amylase the effect of calcium ions. Biochim. Biophys. Acta, 1652, 52-63.

19. Nielsen, J.E.; Borchert, T.V. (2000). Protein engineering of bacterial $\alpha$-amylases. Biochim Biophys. Acta, 1543, 253-274.

20. Nunes, A.S.; Martins, M.L.L. (2001) Isolation, properties and kinetics of growth of a thermophilic Bacillus. Braz. J. Microbiol., 32, 271-275.

21. Phadatare, S.U.; Deshpande, V.V.; Srinivasan, M.C. (1993). High activity alkaline protease from Conidiobolus coronatus (NCL 86.8.20): Enzyme production and compatibility with commercial detergents. Enzyme Microbiol. Technol., 15, 72-76.

22. Sajedi, R.H.; Naderi-Manesh, H.; Khajeh, K.; Ahmadvand, R.; Ranjbar,B.; Asoodeh, A.; Moradian, F. (2005). A Ca-independent $\alpha$ amylase that is active and stable at low $\mathrm{pH}$ from the Bacillus sp. KR8104. Enzyme and Microb. Technol., 36, 666-671.

23. Saxena, R.K.; Dutt, K.; Agarwal, L.; Nayyar, P. (2007). A highly thermostable and alkaline amylase from a Bacillus sp. PN5. Bioresour. Technol., 98(2), 260-265.

24. Sidhu G.S.; Sharma, P.; Chakrabarti, T.; Gupta, J.K. (1997). Strain improvement for the production of a thermostable $\alpha$-amylase. Enzyme and Microb. Technol., 21, 525-530.

25. Sodhi, H.K.; Sharma, K.; Gupta, J.K.; Soni, S.K. (2005). Production of a thermostable $\alpha$-amylase from Bacillus sp. PS-7 by solid state fermentation and its synergistic use in the hydrolysis of malt starch for alcohol production. Process Biochem., 40, 525-534.

26. Van der Maarel, M.J.; Van der Veen, B.; Uitdehaag, J.C.; Leemhuis, H.; Dijkhuizen, L. (2002). Properties and applications of starch-converting enzymes of the $\alpha$-amylase family. J. Biotechnol., 94, 137-155.

27. Volkin, D.B.; Klibanov, A.M. (1989). Thermal destruction processes in proteins involving cysteine. J. Biol. Chem., 262, 2945-2950. 